\title{
Combining ability of early-maturing varieties of soft spring wheat by grain weight from the ear
}

\author{
V.V. Novokhatan, T.V. Shelomentseva, and T.A. Leonova* \\ Federal State Institutions Federal Research Centre Tyumen Scientific Centre of Siberian Branch of the \\ Russian Academy of Sciences (Tyumen Scientific Centre SB RAS)
}

\begin{abstract}
With the participation of early-maturing varieties, a topcross scheme of crossings was performed $(10 \times 4)$; maternal varieties: Pamyati Azieva, Altayskaya 92, Obskaya 14, SURENTa-6, Adeline, SURENTa-3, Voronezhskaya 12, Tyumenskaya rannyaya, Tulun 15, Tyumenskaya 27; testers - Iren, Novosibirskaya 15, Latona, Tulunskaya 12. In 2007, the Pamyati Azieva and Iren had a more productive ear $-0.88 \mathrm{~g}$, in the dry year of 2008 - SURENTa-6, Adeline and Tulun 15 (0.80-0.82). The following strongly react to drought: Voronezhskaya 12, Tyumenskaya rannyaya, Iren, Latona, Novosibirskaya 15 (0.49-0.64 g). The Pamyati Azieva and SURENTa-3 are distinguished by increased CCA. Varieties with multidirectional CCA are recommended for synthetic breeding. SCA is distinguished in: Tyumenskaya rannyaya, SURENTa-3, in better conditions - SURENTa-6, Adeline, Iren, Tulunskaya 12, which allows them to be used in recombination breeding. Varieties with low indicators of CCA and SCA - Altayskaya 92, Obskaya 14, Tulun 15, Tyumenskaya 27 and Latona, are ineffective in breeding for productivity. The heterosis effect on the trait was manifested in $15-20 \%$ of the combinations, more significant in arid conditions.
\end{abstract}

\section{Introduction}

The results of breeding work are largely determined by the source material taken into hybridization, its value for a number of economically valuable traits. The selection of parental pairs is carried out on the basis of an in-depth analysis of the maximally extended genealogic trees varieties - parents [1-3] of their ecological and geographical origin and the dynamics of limiting environmental factors at the geographical point where a particular parent was created [4]. The ability of the variety and line to produce hybrids with increased severity of traits when crossing with other varieties is due to the heterosis effect [5-7]. At the same time, the manifestation of a particular trait in hybrids varies from the conditions in which it manifests [8-10]. The variation of traits in hybrids is more pronounced in more severe conditions of their cultivation [8,9]. The manifestation of traits in hybrids is due to the combining ability of the parental forms - both common (CCA) and specific (SCA) [11-14]. At the same time, the CCA characterizes the average value of the original parental forms in hybrid combinations, and the SCA evaluates varieties based on individual combinations. To assess

\footnotetext{
${ }^{*}$ Corresponding author: tatyanka.leonova.2020@bk.ru
} 
the combining ability, various crossing systems are used: diallel, topcross, polycross. Of these, the topcross method is the easier and more economical [15], which allows at the initial stage of breeding to isolate varieties with low combining ability and various manifestations of the heterosis effect in crossings [16,12].

\section{Purpose of research}

From the variety samples of the VIR collection, we can distinguish early-ripening forms that are well adapted to the conditions of the Northern Trans-Urals. With their participation, to conduct a topcross scheme of crossings $(10 \times 4)$ and, during two contrasting years, to study the grain weight from the ear in the parental varieties and their hybrids. To determine the general and specific ability of the varieties taken into crossing, and the heterosis effect on this trait in hybrids.

\section{Material, methods and conditions of vegetation}

The research was carried out on the experimental field of the Northern Trans-Urals Research Institute, on dark gray soil, black, fertilized $-\mathrm{N}_{30} \mathrm{P}_{30} \mathrm{~K}_{45} \mathrm{~kg}$. r.a./ha of fallow. Among the early-ripening varieties studied in local conditions, varieties that differ in economic and valuable characteristics and productivity are distinguished. The method of selection of genotypes - based on the remoteness of relation, aimed at improving the quantitative and qualitative characteristics, the best of them are used as the source material. With their participation, a topcross scheme of crosspings $(10 \times 4)$ was performed in 2006-2007. The following varieties were taken as maternal forms: Pamyati Azieva, Altayskaya 92, Obskaya 14, SURENTa-6, Adelina, SURENTa-3, Voronezhskaya 12, Tyumenskaya rannyaya, Tulun 15, Tyumenskaya 27. The paternal varieties (testers) were well-studied - Iren, Novosibirskaya 15, Latona and Tulunskaya 12, which are able to improve the maternal shortcomings of the created hybrids. Hybrids of the first generation $\left(F_{1}\right)$ and parental varieties were sown at the optimal time, with a seeding rate of 20 grains per linear meter and a feeding area of $75 \mathrm{~cm}^{2}$ for each plant. Sowing - in a manual planting machine of the SmbNIISkhoz design. The placement of plots is randomized, the repetition is fourfold. The plants of hybrids and parental varieties were harvested manually, with roots. Hybridological analysis was carried out on the elements of the crop structure and productivity, by repetitions, in all harvested plants. Statistical processing and variance analysis of experimental data were carried out according to B.A. Dospekhov (2011) [17]. The calculation of the combining ability of topcross crossing varieties is carried out according to the method described by R.I. Rutz (2005) [12].

The climatic conditions during the growing season were contrasting. At the same time, the year 2007 was close to the average long-term indicators - the HTC for the vegetation = $1.50($ norm $=1.31)$ and was characterized as satisfactory due to the aridity of the 3rd decade of June $(\mathrm{HTC}=0.30)$, the end of July $(\mathrm{HTC}=0.57)$ and mid-August $(\mathrm{HTC}=0.36)$. As a result, the weight of 1000 grains was formed as not high - within 33 grams. The year 2008 was dry, despite the $\mathrm{HTC}=1.54$ - due to heavy rainfall in early June, late July and August (HTC=2.694.02). Almost no precipitation was observed during the critical periods of wheat plant development - in the 2 nd and 3 rd decades of June, the 2 nd decade of July ( $\mathrm{HTC}=0.27 ; 0.16$; $0.00)$ and a significant lack of them in the 2 nd decade of August $(\mathrm{HTC}=0.76)$. Therefore, the formation and filling of grain took place in extreme conditions, which reduced the ear productivity. 


\section{Research results}

The grain weight from the ear, as an integral trait, is the main one in the formation of yields. Therefore, an increase in the yield of soft spring wheat is inextricably linked with an increase in the productivity of the ear. The analysis of the grain weight from the ear in the initial forms and $F_{1}$ hybrids of soft spring wheat shows that the average value of the trait in $F_{1}$ hybrids is higher than in the initial forms. At the same time, in more favorable 2007, the grain weight from the ear was expressed better: in parents $-0.76 \mathrm{~g}$ and in $\mathrm{F}_{1}$ hybrids $=0.82 \mathrm{~g}$, respectively, in arid $2008-0.67 \mathrm{~g}$ and $0.70 \mathrm{~g}$ (Table 1). Among the maternal forms in 2007, the ear was more productive in the variety

Table 1. Weight of grain from the ear in varieties and $F_{1}$ hybrids of soft spring wheat, by year $(\mathrm{g})$

\begin{tabular}{|c|c|c|c|c|c|c|c|c|c|c|c|c|c|c|c|}
\hline \multirow[b]{2}{*}{ No. } & \multirow[b]{2}{*}{ Variety } & \multicolumn{7}{|c|}{2007} & \multicolumn{7}{|c|}{2008} \\
\hline & & $\mathrm{R}$ & $\underline{\underline{2}}$ & 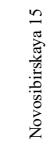 & 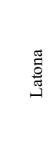 & 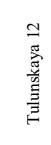 & త্ & $\hat{\mathrm{g} i}$ & $\mathrm{R}$ & פ్ & 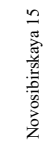 & 罵 & 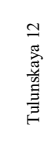 & త্ & $\hat{\mathrm{g} i}$ \\
\hline 1 & $\begin{array}{l}\text { Pamyat } \\
\text { i } \\
\text { Azieva }\end{array}$ & 0.88 & 1.04 & 0.93 & 0.80 & 0.87 & 0.91 & +0.09 & 0.63 & 0,65 & 0,85 & 0,99 & 0,78 & 0,82 & $\begin{array}{l}+0,1 \\
2\end{array}$ \\
\hline 2 & $\begin{array}{l}\text { Altaysk } \\
\text { aya } 92\end{array}$ & 0.73 & 0.91 & 0.83 & 0.79 & 0.79 & 0.83 & +0.01 & 0.72 & 0,71 & 0,71 & 0,73 & 0,65 & 0,70 & 0,00 \\
\hline 3 & $\begin{array}{l}\text { Obskay } \\
\text { a } 14\end{array}$ & 0.79 & 0.93 & 0.77 & 0.85 & 0.86 & 0.85 & +0.02 & 0.69 & 0,71 & 0,71 & 0,71 & 0,71 & 0,71 & $-0,01$ \\
\hline 4 & $\begin{array}{l}\text { SURE } \\
\text { NTa-6 }\end{array}$ & 0.78 & 0.82 & 0.84 & 0.84 & 0.95 & 0.86 & +0.04 & 0.80 & 0,77 & 0,79 & 0,55 & 0,53 & 0,66 & $-0,04$ \\
\hline 5 & Adelin & 0.68 & 0.97 & 0.81 & 0.89 & 0.67 & 0.84 & +0.02 & 0.82 & 0,55 & 0,74 & 0,69 & 0,69 & 0,67 & $-0,03$ \\
\hline 6 & $\begin{array}{l}\text { SURE } \\
\text { NTa-3 }\end{array}$ & 0.69 & 0.89 & 0.82 & 0.93 & 0.80 & 0.86 & +0.04 & 0.70 & 1,04 & 0,84 & 0,54 & 0,70 & 0,78 & $\begin{array}{l}+0,0 \\
8\end{array}$ \\
\hline 7 & $\begin{array}{l}\text { Vorone } \\
\text { zhskay } \\
\text { a } 12\end{array}$ & 0.77 & 0.80 & 0.70 & 0.81 & 0.81 & 0.78 & -0.04 & 0.62 & 0,64 & 0,59 & 0,71 & 0,89 & 0,71 & $\begin{array}{l}+0,0 \\
1\end{array}$ \\
\hline 8 & $\begin{array}{l}\text { Tyume } \\
\text { nskaya } \\
\text { rannya } \\
\text { ya }\end{array}$ & 0.76 & 0.98 & 0.83 & 0.76 & 0.82 & 0.84 & +0.03 & 0.49 & 0,40 & 0,88 & 0,65 & 0,48 & 0,60 & $\begin{array}{c}-0,10 \\
\end{array}$ \\
\hline 9 & $\begin{array}{l}\text { Tulun } \\
15\end{array}$ & 0.77 & 0.71 & 0.81 & 0.70 & 0.61 & 0.71 & -0.11 & 0.80 & 0,41 & 0,73 & 0,56 & 0,69 & 0,60 & $-0,10$ \\
\hline 10 & $\begin{array}{l}\text { Tyume } \\
\text { nskaya } \\
27\end{array}$ & 0.79 & 0.75 & $\begin{array}{l}0.79 \\
\end{array}$ & 0.72 & 0.67 & 0.73 & $\begin{array}{c}-0.09 \\
\end{array}$ & 0.70 & 0,74 & 0,79 & 0,64 & 0,78 & 0,74 & $\begin{array}{l}+0,0 \\
4\end{array}$ \\
\hline 11 & Iren & 0.88 & & & & & & & 0.64 & & & & & & \\
\hline 12 & $\begin{array}{l}\text { Novosi } \\
\text { birskay } \\
\text { a } 15\end{array}$ & 0.65 & & & & & $\mathrm{Xp}=0$ & & 0.54 & & & & & & \\
\hline 13 & Latona & 0.76 & & & & & & & 0.60 & & & & & & \\
\hline 14 & $\begin{array}{l}\text { Tuluns } \\
\text { kaya } 12\end{array}$ & 0.68 & & & & & & & 0.62 & & & & & & \\
\hline & $\mathrm{x}_{\mathrm{r}}$ & 0.76 & & & & & & & 0.67 & & & & & $\mathrm{Xp}=0.7$ & \\
\hline & $\mathrm{CCA}$ & & 0.88 & 0.81 & 0.81 & 0.78 & & & & 0,66 & 0,76 & 0,68 & 0,69 & & \\
\hline & gj & & +0.06 & -0.01 & -0.01 & -0.04 & & & & $-0,04$ & $+0,0$ & $-0,02$ & $-0,01$ & & \\
\hline & & & $\begin{array}{l}\mathrm{LSD}_{0} \\
\text { Sx.\% }\end{array}$ & & & & & & & $\begin{array}{l}\mathrm{LSD}_{0} \\
\text { Sx.\% }\end{array}$ & & & & & \\
\hline
\end{tabular}

Pamyati Azieva is $0.88 \mathrm{~g}$, and testers in Iren - $0.88 \mathrm{~g}$. In the conditions of arid 2008, the most significant productivity of the ear was manifested in SURENTa-6, Adeline and Tulun $15-0.80-0.82 \mathrm{~g}$, which is due to their physiological properties. In comparison with the previous 2007, the maternal varieties react strongly to dry conditions: Voronezhskaya 12 $(0.62 \mathrm{~g})$ and Tyumenskaya rannyaya $(0.49 \mathrm{~g})$, which reduced the productivity of the ear by $24 \%$ and $55 \%$, and from the testers: Iren $(-0.24 \mathrm{~g} ;-38 \%)$ and Latona $(-0.16 \mathrm{~g} ;-27 \%)$. The precocious Novosibirskaya 15 also reacts to dry conditions - $0.65 \mathrm{~g}$ and $0.54 \mathrm{~g}(-0.11 \mathrm{~g}$; $20 \%$ ). Almost at the same, insignificant level, the productivity of the ear, both years, in the fine-grained Tulunskaya $12(0.68$ and 0.67$)$. The value of the trait under these conditions is more stable in Altaiskaya 92 (0.73 and $0.72 \mathrm{~g})$, SURENTa-3 $(0.63 ; 0.70)$, Tulun 15 (0.77 and $0.80 \mathrm{~g})$ and Tyumenskaya $27(0.79$ and $0.70 \mathrm{~g})$. 
The increased total combining ability, both years, is allocated to the Pamyati Azieva variety $(0.91 ; 0.82)$, in which the effects of CCA are positively expressed - $\hat{g} i=+0.09$ and +0.12 , the same is noted in SURENTa-3 $(0.86 ; 0.70$ with $\hat{g} i=+0.04 ;+0.08)$. Therefore, these varieties should be used as initial forms in breeding aimed at increasing the ear productivity. The negative value of the CCA trait in 2007 was expressed in Tulun $15(-0.11)$, Tyumenskaya $27(-0.09)$ and Voronezhskaya $12(-0.04)$. In the dry 2008, the effects of CCA in varieties were expressed ambiguously - negatively in Tulun $15(-0.10)$ and Tyumenskaya rannyaya (0.10). Tulun 15, due to the widespread negative manifestation of the CCA effects, is unpromising in breeding to increase the ear productivity. Among the testers, the positive effect of CCA in 2007 was in Irena ( $\hat{g} i=+0.06)$, and in the dry 2008 - in Novosibirskaya 15 $(\hat{g} i=+0.06)$. Varieties with multidirectional manifestations of the CCA effects can be used in synthetic breeding aimed at increasing the grain weight from the ear.

Indicators of constants (Table 2), as the initial values of the variants reflecting the SCA by grain weight from the ear, in the varieties taken in the crossing, are more pronounced in hybrids with its best manifestation. The specific combining ability of varieties is expressed ambiguously over the years. In the dry year of 2008, the constants of hybrids are expressed more contrastingly, and therefore the values of the variants of the SCA of varieties are more significant here. Both years, according to the SCA indicators, the following are distinguished: Tyumenskaya rannyaya $\left(\delta^{2} \mathrm{sj}=0.703 \times 10^{-2} ; 0.304 \times 10^{-1}\right)$ and SURENTa-3 $\left(\delta^{2} \mathrm{sj}=0,583 \times\right.$ $\left.10^{-2} ; 0,477 \times 10^{-1}\right)$. In the better conditions of 2007 , in this regard, we should note SURENTa$6-\delta^{2} \mathrm{sj}=0.583 \times 10^{-2}$ and Adelina $-\delta^{2} \mathrm{sj}=0.863 \times 10^{-2}$. Low SCA value, both years, in Altaiskaya 92, Obskaya 14, Tyumenskaya 27 and, in arid conditions, in Adelina. Among the SCA testers in contrast conditions, Irene stands out $-\delta^{2} \mathrm{sj}=0.248 \times 10^{-2}$ and $0.227 \times 10^{-1}$. The Tulunskaya $12-\delta^{2} \mathrm{sj}=0.623 \times 10^{-2}$ shows $2.5-3.0$ times higher SCA variants, in the conditions of 2007 , compared with other testers.

Table 2. Components of constants ( $\mathrm{Sij})$ and variants $\left(\delta^{2} \mathrm{si} ; \delta^{2} \mathrm{sj}\right)$ of SCA (by year).

\begin{tabular}{|c|c|c|c|c|c|c|c|c|c|c|c|c|}
\hline \multirow[b]{2}{*}{ No. } & \multirow[b]{2}{*}{ Variety } & \multicolumn{5}{|c|}{2007} & \multicolumn{6}{|c|}{2008} \\
\hline & & 胥 & 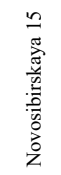 & 营 & 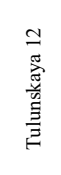 & 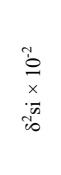 & & Е్ & 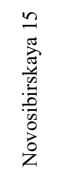 & 总 & 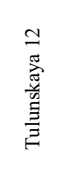 & $\begin{array}{l}\overrightarrow{0} \\
x \\
\dot{n} \\
i 0 \\
i 0\end{array}$ \\
\hline 1 & $\begin{array}{l}\text { Pamyati } \\
\text { Azieva } \\
\end{array}$ & +0.07 & +0.03 & -0.10 & +0.01 & 0.537 & & -0.13 & -0.03 & +0.19 & -0.03 & 0.180 \\
\hline 2 & $\begin{array}{l}\text { Altayskaya } \\
92\end{array}$ & +0.02 & +0.07 & -0.03 & +0.01 & 0.06 & & +0.05 & -0.05 & +0.05 & -0.04 & 0.027 \\
\hline 3 & $\begin{array}{l}\text { Obskaya } \\
14\end{array}$ & +0.02 & -0.07 & +0.01 & +0.05 & 0.266 & & +0.04 & -0.06 & +0.02 & +0.01 & 0.019 \\
\hline 4 & $\begin{array}{l}\text { SURENTa } \\
-6\end{array}$ & -0.10 & -0.01 & -0.01 & +0.13 & 0.606 & & -0.15 & +0.07 & -0.09 & -0.12 & 0.166 \\
\hline 5 & Adelina & +0.07 & -0.02 & +0.06 & -0.13 & 0.863 & & -0.08 & +0.01 & +0.04 & +0.03 & 0.030 \\
\hline 6 & $\begin{array}{l}\text { SURENTa } \\
-3\end{array}$ & -0.03 & -0.01 & +0.08 & -0.10 & 0.583 & & +0.30 & +0.01 & -0.22 & -0.07 & 0.477 \\
\hline 7 & $\begin{array}{l}\text { Voronezhs } \\
\text { kaya } 12\end{array}$ & +0.04 & -0.07 & +0.04 & +0.07 & 0.463 & & -0.03 & $\begin{array}{l}-0.18 \\
\end{array}$ & +0.02 & +0.19 & 0.209 \\
\hline 8 & $\begin{array}{l}\text { Tyumensk } \\
\text { aya } \\
\text { rannyaya }\end{array}$ & +0.08 & +0.01 & -0.07 & -0.02 & 0.703 & & -0.16 & +0.22 & +0.07 & -0.11 & 0.304 \\
\hline 9 & Tulun 15 & +0.01 & +0.11 & +0.01 & -0.06 & 0.436 & & -0.15 & +0.07 & -0.02 & +0.10 & 0.126 \\
\hline 10 & $\begin{array}{l}\text { Tyumensk } \\
\text { aya } 27\end{array}$ & -0.04 & +0.07 & +0.01 & -0.02 & 0.237 & & +0.04 & -0.01 & -0.08 & +0.05 & 0.035 \\
\hline & $\delta^{2} \mathrm{sj} \times 10^{-2}$ & 0.248 & 0.222 & 0.204 & 0.623 & & $\begin{array}{c}\delta^{2} \mathrm{sj} \times \\
10^{-1} \\
\end{array}$ & 0.227 & 0.108 & 0.115 & 0.085 & \\
\hline
\end{tabular}

Varieties with high SCA manifested in both years: SURENTa-3 and Tyumenskaya early and in better conditions - SURENTa- 6 and Adelina, and from testers - Tulunskaya 12 should be used of recombining breeding aimed at increasing the grain weight from the ear. Varieties with low CCA and SCA - Altayskaya 92, Obskaya 14, Tulun 15, Tyumenskaya 27 and tester - Latona, are ineffective in breeding for productivity. 
The discrete nature of the manifestation, by years, of the grain weight from the ear in the parental forms also affected the inheritance of the trait in their hybrids. At the same time, the different manifestation of the trait in hybrids indicates the heterogeneity of its inheritance. Due to the recombining orientation caused by allelic - dominance and overdominance, and non-allelic - epistatic interaction of genes, a heterosis effect is caused. In subsequent generations, positive transgressions are observed in the first case and complex cleavages in the second case, allowing to obtain productive forms.

Its average value of grain weight from ear in populations of $F_{1}$ hybrids in 2007 was 0.82 $\mathrm{g}$, and in $2008-0.70 \mathrm{~g}$. The analysis of $F_{1}$ hybrids (Table 1) shows that in 2007, in 11 combinations $(28 \%)$, the heterosis of ear productivity in relation to the best parent was manifested from $5 \%$ to $22 \%$. At the same time, it was noted more significantly - from $10 \%$ to $22 \%$ in 6 combinations (15\%). In the dry year of 2008 , despite the general decrease in the value of the trait, a fairly pronounced heterosis $(+20 \ldots+48 \%)$ was manifested in 8 combinations $(20 \%)$. It should be noted that the heterosis of the grain weight in the ear both years was manifested, for the most part, in various combinations. In two combinations: Pamyati Azieva $\times$ Novosibirskaya 15 and Voronezhskaya $12 \times$ Tulunskaya 12 it was expressed unambiguously positively $(+6 \% \ldots+12 \ldots+29 \%)$. The ability of these combinations is to form a productive ear in contrasting conditions is of breeding value. In arid conditions (2008), combinations of: Pamyari Azieva $\times$ Latona, Voronezhskaya $12 \times$ Tulunskaya 12 and SURENTa-3 $\times$ Iren, with a fairly pronounced heterosis (29\%-48\%) and a good value of the trait- 0,89-0,99-1,04 g, have breeding value in modern, often changing climatic conditions.

Under more favorable conditions (2007), when the value of the grain weight from ear was higher in most varieties and hybrids, the effect of heterosis was less pronounced. Here, among the studied hybrids, with an increased trait value - from 0.93 to 1.04 and heterosis from 10 to $22 \%$, the following combinations were distinguished: Pamyati Azieva $\times$ Iren, Pamyati Azieva $\times$ Novosibirskaya 15 , Adelina $\times$ Iren, Tyumenskaya rannyaya $\times$ Iren, SURENTa-3 $\times$ Latona and SURENTa- $6 \times$ Tulunskaya 12 . These combinations are acceptable for breeding, for productivity for intensive farming.

The selected varieties according to the general and specific combinational ability of the grain weight from the ear are included in the breeding programs, where a fairly extensive breeding material has been created with their participation. So, in the competitive variety testing of 2021, 7 lines are being tested with their participation, 13 lines are being tested in PSI and KP. At the same time, the most effective populations, where the varieties allocated according to CCA and SCA, are used as paternal forms and their subsequent continuous onetwo-fold saturation. An example of this is the early-ripening lines studied at the final stages of breeding: No. 428 (Obskaya $\times$ Tulunskaya 12) $\times$ Tulunskaya 12; No. 138, 283 (Obskaya $\times$ Tulunskaya 12) $\times 2$ Tulunskaya 12 ; No. $1220-($ Novosibirskaya $15 \times$ Iren $) \times 2$ Iren and No. 112 - (SURENTa-3 $\times$ Pamyati Azieva) x Pamyati Azieva. The same applies to the earlyripening, valuable in quality variety Grenada, created and registered in 2019-2020, the elite plant of which was selected from a combination (Kazakhstanskaya rannespelaya $\times$ Tulunskaya 12) $\times$ Tulunskaya 12, and transferred to the GSI (2020) variety Atlanta 2 - (Aisi $\times$ Latona) $\times$ Latona.

\section{Conclusions}

Varieties: Pamyati Azieva and SURENTa-3 are distinguished by an increased CCA, which determines their breeding value. Varieties with multidirectional effects of CCA over the years can be used in synthetic breeding.

SCA is expressed in Tyumenskaya rannyaya, SURENTa-3 and in better conditions SURENTa-6, Adelina, Iren and Tulunskaya 12, which allows them to be used in recombining breeding. 
Varieties with low indicators of CCA and SCA - Altayskaya 92, Obskaya 14, Tulun 15, Tyumenskaya 27 and Latona, are ineffective in breeding for productivity.

The heterosis effect on the grain weight from the ear over the years was manifested in 15$20 \%$ of combinations, more significant $(+29 \ldots+48 \%)$ in arid conditions. In combinations: Pamyati Azieva $\times$ Novosibirskaya 15 and Voronezhskaya $12 \times$ Tulunskaya 12 heterosis effect $(+6 \ldots+12 \ldots+29)$ appeared in different growing conditions, which increases their breeding value.

\section{Acknowledgements}

*The work was performed according to the state task No. 121041600036-6

\section{References}

1. T. Ushiyama, K. Nakamura, T. Anas Yoshida, Plant Prod. Sci. 12(1), 80-87 (2009)

2. J.R. Witcombe, D.S. Virk, Plant breeding and farmer participation, 129-138 (Rome, 2009)

3. V.V. Novokhatin, Achievements of Science and Technology in agriculture (3), 42-45 (2016)

4. V.V. Novokhatin, V.A. Dragavtsev, T.A. Leonova, T.V. Shelomentseva, Agricultural biology, 54 (5), 905-919 (2019)

5. A.A. Zhuchenko, Ecological genetics of cultivated plants. Chisinau. "Stiinza", 586 (1980)

6. S. Islam, P.S.L. Srivastava, Bangladesh J.agr.Res., 26 (I), 1-6 (2001)

7. C. Akinci, Bulg.J.agr.Sc., 15 (3), 214-221 (2009)

8. V.A. Dragavtsev, R.A. Tsilke, B.G. Reiter, V.A. Vorobyova, A.G. Dubrovskaya, N.I. Korobeynikov, V.V. Novokhatin, V.P. Maksimenko, A.G. Babakishiev, V.G. Ilyushenko, N.A. Kalashnik, Yu.P. Zuikov, A.M. Fedotov, Genetics of productivity traits of spring wheat in Western Siberia, 230 (Novosibirsk: Nauka, 1984)

9. R.A. Tsilke, Genetics, cytogenetics and plant breeding, 621 (Col. of scientific proc. Novosibirsk, 2003)

10. V. Gahlaut, V. Jaiswal, B.S. Tyagi, G. Singh, S. Sareen, H.S. Balyan, P.K. Gupta, PLoS, 12(8), (2017)

11. K. Szwed-Urbas, Z. Segit, D. Zalewski, Biul.Inst.Hodowli Aklimat.Rosl, 216 (2), 343350 (2001)

12. R.I. RutzScientific bases and practical results of breeding of spring wheat and winter bluegrass crops in Western Siberia, Novosibirsk, 623 (2005)

13. L.L. Lysa, Physiology and biochemistry of cult. plants. 41 (3), 242-247 (2009)

14. W. Kociuba, Z. Segit, W. Kadlubiec, R. Kuriata, Biul.Inst.Hodowli Aklimat. Rosl. Warszawa, 264, 43-48 (2012)

15. R.L. Davis, Report of the Plant Breeder, Rept.Puerto Rico Agr.Expert.Sta.: 14-15 (1927)

16. A.A. Hamada, E.H. el-Seidy., H.I. Hendawy, Ann.agr.Sc., 47 (2), 587-609 (2002)

17. B.A. Dospekhov, Methodology of field experience. Ed. 6th revision. and suppl., 351 (Moscow: Agropromizdat, 2011) 